\section{Role of estrogen and estrogen receptors in cancer pathology}

\author{
Vesna Mandusic,1 Djordje Radak,2 \\ Milan Markicevic, ${ }^{3}$ Milan Perovic, 4 \\ Milan Obradovic, ${ }^{1}$ Dimitri P. Mikhailidis, ${ }^{5}$ \\ Esma R. Isenovic ${ }^{1}$
}

1Laboratory for radiobiology and molecular genetics, Institute Vinca, University of Belgrade, Serbia;

2Department of Vascular Surgery, Dedinje Cardiovascular Institute, Belgrade University School of Medicine, Belgrade, Serbia;

3Institute for Oncology and Radiology of Serbia, Belgrade, Serbia

${ }^{4}$ Clinical Hospital Center Zemun, Department of Gynecology, Zemun, Serbia;

5Department of Clinical Biochemistry (Vascular Disease Prevention Clinics), Royal Free campus, University College London Medical School, University College London (UCL), London, UK

\section{Abstract}

Estrogen regulates many different and sometimes quite opposite processes in cells. Since the discovery of estrogen receptor (ER), the last few decades have resulted in a better understanding of estrogen biology. Estrogen is involved in processes leading to different pathologies in estrogen responsive tissues, not only carcinogenesis, but this was one of the most investigated fields in estrogen-related pathology. The exact role of estrogen in these pathologies is not completely understood due to the complex interplay of its receptors with other signaling pathways. This review considers the latest literature focused on estrogen and ERs as potential therapeutic targets in the treatment of malignant disease (e.g. breast, prostate, ovarian and endometrial cancer).

\section{Introduction}

Hormones regulate basic biological processes of mediating signals into the cells. There are two major types of hormones: peptide and steroid and their receptors are located in cell membrane and/or cytoplasm. Upon binding to their receptors, hormones activate different signaling pathways in cells regulating the processes of cell division, differentiation and apoptosis. ${ }^{1}$ Moreover, endogenous and exogenous hormones, and hormone-like substances are involved in the etiology of cancer, neurodegenerative diseases and many other pathologies. ${ }^{1}$ In carcinogenesis, hormones are involved in initiation but also in the progression of disease. ${ }^{2}$ However, due to an apoptotic effect, some hormones might have the opposite effect; for example reduce cancer risk or slow down tumor progression. ${ }^{2}$ On the other hand, a preserved functional hormonal pathway represents a target for anti-hormonal therapy in endocrine-related malignancies, such as breast, endometrial, ovary, prostate or testis cancers. Hormone-related carcinogenesis is of very complex etiology due to the combination of genetic susceptibility, epigenetic changes and exposure to endogenous and exogenous hormones and hormone-like substances.

Estrogen is the hormone involved in etiology of carcinogenesis in responsive tissues, such as the endometrium, breast, ovary and prostate, which are the models for studying hormonal carcinogenesis. ${ }^{3}$ The main effects of estrogen is usually mediated through its receptors, thereby their expression patterns (in addition to hormonal exposure and exposure to other risk factors) are one of the major determinants of incidence and progression of disease. ${ }^{4-6}$ Expression profiling in cancer is still an open issue, despite the intensive efforts in microarray-based studies.7-10

In this review, we present some aspect of this complexity related to estrogen and its receptors as potential therapeutic targets.

\section{Estrogen function}

Since the discovery of estrogen receptor (ER) in the 1950's, it was realized that estrogen is much more than a sex hormone. It regulates many different and sometime quite opposite processes in cells such as: growth and differentiation. ${ }^{11}$ Estrogen is involved in morphogenesis of the mammary gland, prostate and lungs; it is a trophic factor for neurons, and it is involved in maintaining the normal structure of mammary epithelium and fertility in females.

ERs belong to the large family of nuclear receptors. These are the family of structurally related ligand-inducible transcription factors including steroid receptors (SRs), vitamin D receptors (VDR, LXR, PPARs), thyroid/retinoid receptors (TR, RARs and RXRs) and orphan receptors. All nuclear receptors share similar structure and are activated by small lipophilic molecules: glucocorticoids, progesterone, estrogens, retinoids and fatty acid derivatives. ${ }^{12}$

\section{Mechanisms of estrogen action}

There are several ways how estrogen and ER acts on cells. The main and one of the first recognized is the interaction of estrogen with ER into estrogen-ER complex, may act directly on
Correspondence: Esma Isenovic, Institute Vinca, University of Belgrade, Laboratory for Radiobiology and Molecular Genetics, P.0.Box 522 11000 Belgrade, Serbia.

Tel/Fax. +38111.8066868

E-mail: isenovic@yahoo.com.

Key words: estrogen, breast cancer, prostate cancer, ovarian cancer, endometrial cancer.

Acknowledgements: this work was supported by grants No.173033 (to Dr E. R. Isenovic), No.41002 (to Dr Dj. Radak), No.173049 (Dr V. Mandusic.) and No.175068 (M.Sci. M. Markicevic) from the Ministry of Science, Republic of Serbia.

Contributions: all the authors read and approved the manuscript, and believe that it is an original article, which carries new literature findings that are important to their field and encourage more research in this area.

Conflict of interest: the authors report no conflicts of interest.

Received for publication: 29 March 2011.

Accepted for publication: 19 April 2011.

This work is licensed under a Creative Commons Attribution 3.0 License (by-nc 3.0).

(C) Copyright V. Mandusic et al., 2011

Licensee PAGEPress, Italy

Endocrinology Studies 2011; 1:e5

doi:10.4081/es.2011.e5

estrogen response elements (ERE) in the promoters of estrogen responsive genes or may act by interacting with AP- $1^{13}$ or SP-1 complexes. ${ }^{14,15}$ This ligand-dependant activation of transcription via direct genomic action trough ERE or tethering to other proteins is influenced by ligand, ER subtype and expression of different cell specific coregulators. Another mechanism, so called rapid nongenomic mechanism is not well investigated, but it is associated either with membrane $\mathrm{ER}^{16-18}$ or with some other membrane or cytoplasmic protein. ${ }^{19}$ The ligand-dependant pathways of estrogen action are shown in Figure 1. The ligand-independent mechanism of ER activation involves growth factor signaling and kinases that phosphorylate ER and thereby activate it in the absence of a ligand. ${ }^{20-23}$

There are two receptors for estrogen, ER $\alpha$ (estrogen receptor alpha) and ER $\beta$ (estrogen receptor beta), and both receptors are widely expressed in tissues; the main receptor in breast and uterus (as primary target tissues for estrogen) is ER $\alpha$, while ER $\beta$ seems to be the main receptor in peripheral tissues (bladder, lung, intestines and glands). Although structurally highly homologous, ER $\alpha$ and ER $\beta$ may have opposite functions on some promoters. Therefore, their ratio might determine transcription from downstream target genes, in cells where both are expressed. ${ }^{24}$ It has been 
shown that ER $\alpha$ complex with estrogen stimulate transcription from an AP1 sites, while ER $\beta$ inhibits it. ${ }^{25}$ However, this is not a general model, but rather promoter specific, since in tumor necrosis factor alpha (TNF- $\alpha$ ) promoter's AP-1 site, ER $\alpha$ and ER $\beta$ shows similar activity. ${ }^{26}$

In many cell types estrogen stimulates proliferation and inhibits apoptosis, but in others, estrogen induces apoptosis. ${ }^{27,28}$ Cell growth by estrogen is achieved by induction of transition from G1- to S-phase of the cell cycle, through upregulation of $c$-myc which controls cyclin D expression. ER $\alpha$ also interacts with number of proteins (growth factor receptors and mitogen activated kinases) involved in activation of mitosis. ${ }^{29-32}$ Conversely, in some breast and prostate cancer cells after long-term estrogendeprivation estrogen may induce mitochondrial pathway of apoptosis.33-35 To date, apoptotic action of estrogen is mainly addressed to the upregulation of FasL gene expression either via direct genomic action on ERE in the promoter region of FasL gene ${ }^{36}$ or via interaction with AP-1 and SP-1 proteins. 37,38 This dual role of a single hormone needs to be further resolved in the different cell types and physiological conditions. The apoptotic effects of estrogen may be applicable in the clinical management of postmenopausal breast cancer patients treated with tamoxifen, the group in which estrogen may induce tumor regression as well in estrogen negative breast cancer. ${ }^{39}$

Genomic organization of genes coding for $\mathrm{ER} \alpha(E S R 1)$ and $\mathrm{ER} \beta$ (ESR2) is very complex. Both ESR1 and ESR2 genes have complex organization of multiple promoters and differential splicing in 5'-UTR region. ${ }^{40-42}$ Such complex organization of multiple promoters is probably responsible for the tissue specific expression of these receptors. One of the mechanisms of generating the isoforms, like $\mathrm{ER} \alpha 46 \mathrm{kD}$, is alternative usage of transcription start site. Exon deletions or duplications are second mechanisms that potentially generate changes in the open reading frame and, accordingly, lead to different forms of proteins. ${ }^{43,44}$ In addition, $5 \mathrm{ER} \beta$ isoforms (designated as ER $\beta 1$ - ER $\beta 5$ ) originate by alternative usage of the eighth coding exon.45,46 The presence of numerous isoforms/splice variants of both ER $\alpha$ and ER $\beta$ suggests the complex regulation of estrogen action. The exact biological significance of isoforms and their splice variants of both ER $\alpha$ and ER $\beta$ receptors is still unclear but it seems that their existence may regulate the cellular response to estrogen. ${ }^{41,43,47}$

Similar genomic organization and alternatively spliced mRNA, producing variant proteins is common among the other members of steroid receptors: androgen receptor (AR), progesterone receptor (PR) and glucocorticoid receptor (GR). ${ }^{48,49}$

Alternative promoter usage and presence of numerous variant proteins with possibly dif-

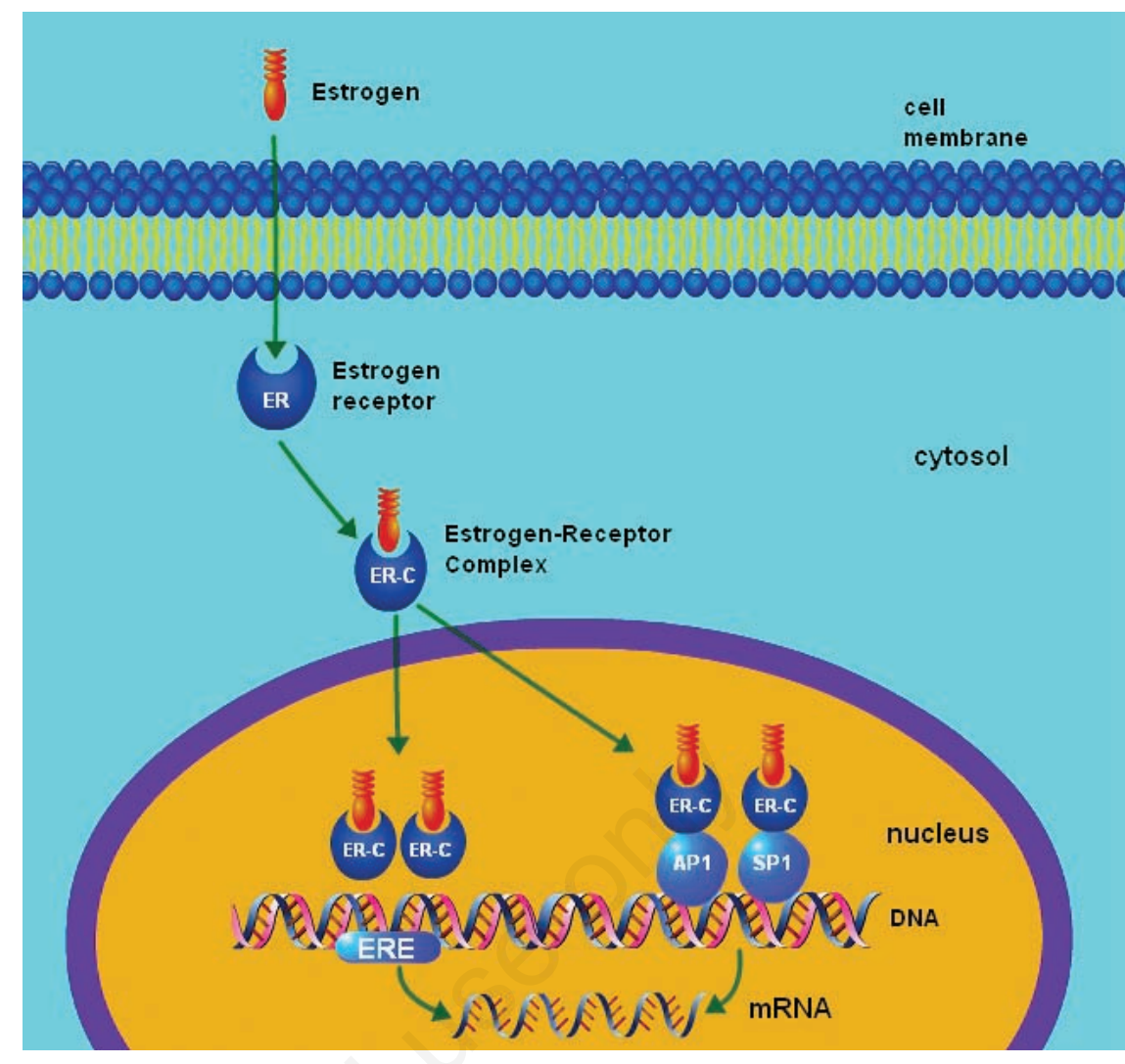

Figure 1. The ligand- dependant pathways of estrogen. Estrogen receptor indicates indicates estrogen receptor; AP1 and SP1 indicates transcriptional factors; estrogen response elements indicates estrogen responses elements. Figure was created by using drawing tools from www. ProteinLounge.com

ferent interacting properties may explain the broad spectrum of different and sometimes quite opposite tissue-, age- and physiologicalspecific functions of the same hormone.

\section{Role of estrogen in cancer pathology}

There are two possible ways how estrogen initiates and promotes carcinogenesis; i) via its proliferative effects which increase the numbers of cell divisions and accumulation of mutations in DNA; ii) via estrogen metabolism accumulation of intermediary products with genotoxic effect in cells. ${ }^{50,51}$

\section{Breast cancer}

It is well known that $50-80 \%$ of breast carcinoma patients have tumors with measurable $\mathrm{ER} \alpha$ levels, i.e. ER $\alpha+$ tumors; $52 \mathrm{ER} \alpha+$ tumors are sensitive to endocrine therapy. ${ }^{53}$ More than half of ER $\alpha+$ breast carcinomas express progesterone receptor (PR) ${ }^{54}$ that mediates progesterone's effects in the development of the mammary gland and breast carcinoma, where estrogen signaling via $\mathrm{ER} \alpha$ is necessary to induce PR expression.55 The status of ER/PR (or steroid receptors), for primary breast cancer patients is accepted to provide potentially relevant information regarding natural or clinical course of disease. ${ }^{56}$ While steroid receptor status of the primary breast cancer is a prognostic indicator for patient's outcome, though it is considered a weak one, ${ }^{57}$ it has been proven to be a predictor of response to endocrine therapy since up to $80 \%$ of patients bearing $\mathrm{ER}+\mathrm{PR}+$ tumors respond to endocrine treatment. 58

The facts that steroid status is not a powerful prognostic marker, that some breast cancers patients with steroid receptors-negative status respond to endocrine treatment and that certain number of breast carcinomas will recur after such treatment in spite of steroid receptors-positivity emphasize the need for identifying markers complementary to SR status in order to improve the prognosis and prediction of breast cancer patients. Attention has been directed to estrogen-regulated proteins, including $\mathrm{pS} 2$, cathepsin D and ER $\beta$, assuming that these proteins may be indicators of a functional signal transduction pathway through which tumor cells respond to estrogen (or antiestrogen) stimulation. In addition, the new markers related to cell cycle regulation and those detectable in circulating DNA are under intensive investigation. ${ }^{5}$ 
From a tumor biology point of view, considering possible clinical application, it is important to determine the cut-off value for defining estrogen- $v s$ non-estrogen-regulated expression of a protein in breast cancer. Regarding pS2 or cathepsin D, discrimination of estrogenregulated from non-estrogen-regulated protein expression in breast cancer, based on the cutoff value having not only statistical but also biological relevance, ${ }^{59}$ might be helpful in order to identify patients with low or high risk for developing metastases (our unpublished data) during early follow-up.

The role of ER $\beta$ and its predictive value in breast cancer is still not clear, but there is evidence that $E R \beta$ transcription is down regulated during breast tumorigenesis. It has been shown that the expression of ER $\alpha$ increases during the process of carcinogenesis, but the expression of $\mathrm{ER} \beta$ seems to decrease. ${ }^{60} \mathrm{ER} \beta$ is under intensive investigation and its role in breast cancer appears to be of additional predictive value.

Selective estrogen receptor modulators (SERMs) are used in clinical management of $\mathrm{ER} \alpha$ positive breast cancer. However, about $30 \%$ of breast cancers are initially ER negative and resistant to endocrine therapies. ${ }^{61}$ In addition, some initially ER positive breast cancers evolve to an estrogen-independent growth phenotype. ${ }^{61}$

Moreover, it has became clear that ERs and PR in living cells represent a pool of different variant proteins; therefore, it is reasonable to propose that ER/PR status should now include $\mathrm{ER} \alpha, \mathrm{ER} \beta$ and PR receptors together with some of their isoforms and functionally active splice variants. The several isoforms of ERs described at protein level and the presence of numerous mRNA splice variants suggest the possibility that expressional profile of these variant proteins tumors might be involved in tumor progression ${ }^{62}$ and tamoxifen resistance. ${ }^{63-65}$

\section{Prostate cancer}

In addition to androgens, estrogens also play an important role in the development of the male reproductive system. Clinical studies shows that increased estrogen serum level or increased estrogen/androgen ratio are associated with increased risk of prostate cancer. ER $\beta$ was initially cloned from prostate tissue. ${ }^{6}$ The facts that this receptor is highly expressed in prostate and that ER $\beta$-, but no ER $\alpha$-knockout mice displayed prostatic epithelial hyperplasia underlie the involvement of ER $\beta$ etiology of prostate hyperproliferative disease and cancer. ${ }^{67-70}$ Interestingly, ER $\beta$ isoforms profiling in the human prostate cancer shows that ER $\beta 2$ isoform was inversely associated with ER $\beta 1$ expression, ${ }^{71}$ and that ER $\beta 2$ correlates with poor prognosis in this disease. The biological significance of this correlation is not clear since ER $\beta 2$ has low affinity to estradiol,46 but inhibits ER $\alpha$-mediated estrogen signalization. A study in laser capture microdissected prostate cancer specimens also confirmed the increase ER $\beta$ mRNA expression compared with normal controls, but without detection of which isoform contributes to this finding. ${ }^{72}$ The authors also found non-significant trend to decreased ER $\alpha$ expression in prostate cancer tissue.

Because of the controversial findings of immunohistochemical and RNA-based studies, the exact role of ER $\alpha$ and $E R \beta$, as well as androgen receptors in prostate carcinogenesis is not yet defined.

\section{Ovarian cancer}

The majority of ovarian cancers arise from the ovarian surface epithelium and only $5 \%$ from the granulosa cells. About $70 \%$ of all ovarian cancers are ER-positive, but tamoxifen does not have therapeutic potential as in breast cancer. ${ }^{73}$ Regarding the ERs subtype, $\mathrm{ER} \alpha$ is expressed in tumors of epithelial and stromal origin, whereas ER $\beta$ is expressed in granulosa cell tumors point ${ }^{74-76}$ With analogy to other hormone responsive tissues, the role estrogen can be expected in etiology of ovarian tumors (at least those that arise from epithelial cells). Moreover, in the etiology of ovarian carcinogenesis gonadotropin stimulation is included, increasing the endogenous estrogen levels produced by the granulosa cells during the reproductive age.1,77 To date, the role of estrogen and ERs in ovarian cancer is not elucidated; this is an issue that may be partially related to the expression of different ER isoforms in ovarian carcinomas. ${ }^{78,79}$ However, in recent years the results of studies in women on long-term hormone replacement therapy showed an increased ovarian cancer incidence (together with increased mortality and other diseases related to hormonal treatment). ${ }^{80-82}$

In general, progestins and ER $\beta$ seems to play a protective role against development of ovarian cancer, like in breast and prostate carcinomas. Decreases in ER $\beta$ expression or increased $\mathrm{ER} \alpha / \mathrm{ER} \beta$ ratio in ovarian cancer is reported. $.99,83,84$

\section{Endometrial cancer}

Although ER $\beta$ are expressed in most cell types in the uterus, the ER $\alpha$ is the main mediator of estrogen action in this organ. The vast majority of sporadic endometrial carcinomas are classified as type I carcinomas and are estrogen-related. 85 These estrogen-related endometrial carcinomas are associated with long-term exposure to estrogen in the absence of sufficient levels of progesterone. ${ }^{86}$ Tamoxifen, routinely used as adjuvant treatment in breast cancer and in breast cancer prevention trials in perimenopausal women, ${ }^{87}$ increases the risk for endometrial cancer. This is a consequence of the agonist effect of tamoxifen on ERs in the uterus. The fact that ER $\beta$ is also expressed in the uterus suggests its potential role in pathogenesis of this disease. However, its role in endometrial carcinogenesis is rather unclear, partially due to the controversial reports of estrogen induced-ER $\beta$ transcriptional activity uterine cell lines. ${ }^{15,88,89}$ To date, the main efforts should be directed towards the investigation of the newer selective estrogen receptor modulators in the terms of their endometrial safety. ${ }^{9}$

\section{Conclusions}

Estrogen plays an important role in development and normal function of tissues during the prenatal development, puberty and in adult age, especially during the fertile period. Consequently, estrogen is involved in processes leading to different pathologies in estrogen responsive tissues, not only in carcinogenesis, but this was one of the most investigated fields in estrogen-related pathologies to date. The exact role of estrogen in these pathologies still is not well understood due to the complex interplay of its receptors with other signaling pathways. On the other hand, today is clear that ERs actually represent a pool of a number of isoforms and splice variants; the expressional profile of these variant proteins with different biological properties (e.g. ligand, DNA and co-factor binding) is probably cell-, tissueand disease-specific. Moreover, most variants might have a predictive value and may represent new potential therapeutic targets.

\section{References}

1. Gardner D, Shoback D. Greenspan's Basic \& Clinical Endocrinology. $8^{\text {th }}$ ed. Shanahan J, Linskey P, eds. New York: McGraw-Hill; 2007.

2. Li SA, Mohla S, Rochefort H, Maudelonde T, eds. Hormonal Carcinogenesis. Springer; 2010.

3. Henderson BE, Feigelson HS. Hormonal carcinogenesis. Carcinogenesis 2000;21:427-33.

4. Hayashi S, Yamaguchi Y. Estrogen signaling in cancer microenvironment and prediction of response to hormonal therapy. $\mathrm{J}$ Steroid Biochem Mol Biol 2008;109:201-6.

5. Weigel MT, Dowsett M. Current and emerging biomarkers in breast cancer: prognosis and prediction. Endocr-Relat Cancer 2010; 17:R245-62.

6. Herynk MH, Fuqua SA. Estrogen receptor mutations in human disease. Endocr Rev 2004;25:869-98.

7. Kim C, Paik S. Gene-expression-based pro- 
gnostic assays for breast cancer. Nat Rev Clin Oncol 2010;7:340-7.

8. Pusztai L. Current status of prognostic profiling in breast cancer. Oncologist 2008; 13:350-60.

9. Badve S, Dabbs DJ, Schnitt SJ, et al. Basallike and triple-negative breast cancers: a critical review with an emphasis on the implications for pathologists and oncologists. Mod Pathol 2011;24:157-67.

10. Rakha EA, Reis-Filho JS, Baehner F, et al. Breast cancer prognostic classification in the molecular era: the role of histological grade. Breast Cancer Res 2010;12:207.

11. Khan SA, Stancel GM. Protooncogenes and growth factors in steroid hormone induced growth and differentiation. CRC Press Inc; 1994.

12. Aranda A, Pascual A. Nuclear hormone receptors and gene expression. Physiol Rev 2001;81:1269-304.

13. Kushner PJ, Agard DA, Greene GL, et al. Estrogen receptor pathways to AP-1. J Steroid Biochem Mol Biol 2000;74:311-7.

14. Heldring N, Isaacs GD, Diehl AG, et al. Multiple sequence-specific DNA-binding proteins mediate estrogen receptor signaling through a tethering pathway. Mol Endocrinol 2011;25:564-74.

15. Saville B, Wormke M, Wang F, et al. Ligand, cell-, and estrogen receptor subtype (alpha/beta)-dependent activation at GCrich (Sp1) promoter elements. J Biol Chem 2000;275:5379-87.

16. Levin ER. Cell localization, physiology, and nongenomic actions of estrogen receptors. J Appl Physiol 2001;91:1860-7.

17. Kelly MJ, Levin ER. Rapid actions of plasma membrane estrogen receptors. Trends Endocrinol Metab 2001;12:152-6.

18. Li L, Haynes MP, Bender JR. Plasma membrane localization and function of the estrogen receptor alpha variant (ER46) in human endothelial cells. Proc Natl Acad Sci U S A 2003;100:4807-12.

19. Walsh DE, Dockery P, Doolan CM. Estrogen receptor independent rapid non-genomic effects of environmental estrogens on $[\mathrm{Ca} 2+] \mathrm{i}$ in human breast cancer cells. Mol Cell Endocrinol 2005;230:23-30.

20. Kato S, Endoh H, Masuhiro Y, et al. Activation of the estrogen receptor through phosphorylation by mitogen-activated protein kinase. Science 1995;270: 1491-4.

21. Isenovic ER, Divald A, Milivojevic N, et al. Interactive effects of insulin-like growth factor-1 and beta-estradiol on endothelial nitric oxide synthase activity in rat aortic endothelial cells. Metabolism 2003;52:4827.

22. Sudar E, Dobutovic B, Milosavljevic T, et al. Interactive effects of insulin and $\beta$-estradiol on protein kinase B phosphorylation in adult rat cardiomyocytes. Acta Chim Sloven
2009;55:354-8.

23. Koricanac G, Tepavcevic S, Zakula Z, et al. Interference between insulin and estradiol signaling pathways in the regulation of cardiac eNOS and $\mathrm{Na}(+) / \mathrm{K}(+)$-ATPase. Eur J Pharmacol 2011;655:23-30.

24. Matthews J, Gustafsson JA. Estrogen signaling: a subtle balance between ER alpha and ER beta. Mol Interv 2003;3:281-92.

25. Liu MM, Albanese C, Anderson CM, et al. Opposing action of estrogen receptors alpha and beta on cyclin D1 gene expression. J Biol Chem 2002;277:24353-60.

26. An J, Ribeiro RC, Webb P, et al. Estradiol repression of tumor necrosis factor-alpha transcription requires estrogen receptor activation function-2 and is enhanced by coactivators. Proc Natl Acad Sci USA 1999; 96:15161-6.

27. Lewis-Wambi JS, Jordan VC. Estrogen regulation of apoptosis: how can one hormone stimulate and inhibit? Breast Cancer Res 2009;11:206.

28. Helguero LA, Faulds MH, Gustafsson JA, Haldosen LA. Estrogen receptors alfa (ERalpha) and beta (ERbeta) differentially regulate proliferation and apoptosis of the normal murine mammary epithelial cell line HC11. Oncogene 2005;24:6605-16.

29. Pietras RJ, Marquez-Garban DC. Membrane-associated estrogen receptor signaling pathways in human cancers. Clin Cancer Res 2007;13:4672-6.

30. Arpino G, Wiechmann L, Osborne CK, Schiff R. Crosstalk between the estrogen receptor and the HER tyrosine kinase receptor family: molecular mechanism and clinical implications for endocrine therapy resistance. Endocr Rev 2008;29:217-33.

31. Stoica GE, Franke TF, Wellstein A, et al. Estradiol rapidly activates Akt via the ErbB2 signaling pathway. Mol Endocrinol 2003;17:818-30.

32. Moriarty K, Kim KH, Bender JR. Minireview: estrogen receptor-mediated rapid signaling. Endocrinology 2006;147:555763.

33. Lewis JS, Meeke K, Osipo C, et al. Intrinsic mechanism of estradiol-induced apoptosis in breast cancer cells resistant to estrogen deprivation. J Natl Cancer Inst 2005;97: 1746-59.

34. Jordan VC, Lewis JS, Osipo C, Cheng D. The apoptotic action of estrogen following exhaustive antihormonal therapy: a new clinical treatment strategy. Breast 2005; 14:624-30.

35. Robertson CN, Roberson KM, Padilla GM, et al. Induction of apoptosis by diethylstilbestrol in hormone-insensitive prostate cancer cells. J Natl Cancer Inst 1996;88: 908-17.

36. Mor G, Kohen F, Garcia-Velasco J, et al. Regulation of fas ligand expression in breast cancer cells by estrogen: functional differences between estradiol and tamoxifen. J Steroid Biochem Mol Biol 2000;73: 185-94.

37. Kasibhatla S, Brunner T, Genestier L, et al. DNA damaging agents induce expression of Fas ligand and subsequent apoptosis in T lymphocytes via the activation of NFkappa B and AP-1. Mol Cell 1998;1:543-51.

38. Kavurma MM, Santiago FS, Bonfoco E, Khachigian LM. Sp1 phosphorylation regulates apoptosis via extracellular FasL-Fas engagement. J Biol Chem 2001;276:496471.

39. Jordan VC, Lewis-Wambi JS, Patel RR, e al. New hypotheses and opportunities in endocrine therapy: amplification of oestrogen-induced apoptosis. Breast 2009;18: S10-7.

40. Flouriot G, Griffin C, Kenealy M, et al. Differentially expressed messenger RNA isoforms of the human estrogen receptoralpha gene are generated by alternative splicing and promoter usage. Mol Endocrinol 1998;12:1939-54.

41. Lewandowski S, Kalita K, Kaczmarek L. Estrogen receptor beta. Potential functional significance of a variety of mRNA isoforms. FEBS Lett 2002;524:1-5.

42. Sand P, Luckhaus C, Schlurmann K, et al. Untangling the human estrogen receptor gene structure. J Neural Transm 2002;109: 567-83.

43. Bollig A, Miksicek RJ. An estrogen receptor-alpha splicing variant mediates both positive and negative effects on gene transcription. Mol Endocrinol 2000;14:634-49.

44. Poola I, Abraham J, Baldwin K. Identification of ten exon deleted ERbeta mRNAs in human ovary, breast, uterus and bone tissues: alternate splicing pattern of estrogen receptor beta mRNA is distinct from that of estrogen receptor alpha. FEBS Lett 2002;516:133-8.

45. Moore JT, McKee DD, Slentz-Kesler K, et al. Cloning and characterization of human estrogen receptor beta isoforms. Biochem Biophys Res Commun 1998;247:75-8.

46. Ogawa $\mathrm{S}$, Inoue $\mathrm{S}$, Watanabe $\mathrm{T}$, et al. Molecular cloning and characterization of human estrogen receptor betacx: a potential inhibitor ofestrogen action in human. Nucleic acids research 1998;26:3505-12.

47. Erenburg I, Schachter B, Mira y Lopez R, Ossowski L. Loss of an estrogen receptor isoform (ER alpha delta 3) in breast cancer and the consequences of its reexpression: interference with estrogen-stimulated properties of malignant transformation. Mol Endocrinol 1997;11:2004-15.

48. Yudt MR, Cidlowski JA. The glucocorticoid receptor: coding a diversity of proteins and responses through a single gene. Mol Endocrinol 2002;16:1719-26. 
49. Hirata S, Shoda T, Kato J, Hoshi K. Isoform/variant mRNAs for sex steroid hormone receptors in humans. Trends Endocrinol Metab 2003;14:124-9.

50. Benz CC, Yau C. Ageing, oxidative stress and cancer: paradigms in parallax. Nat Rev Cancer 2008;8:875-9.

51. Miro AM, Sastre-Serra J, Pons DG, et al. 17beta-Estradiol regulates oxidative stress in prostate cancer cell lines according to ERalpha/ERbeta ratio. J Steroid Biochem Mol Biol 2011;123:133-9.

52. Saez S, Cheix F, Asselain B. Prognostic value of estrogen and progesterone receptors in primary breast cancer. Breast Cancer Res Treat 1983;3:345-53.

53. Osborne CK. Steroid hormone receptors in breast cancer management. Breast Cancer Res Treat 1998;51:227-38.

54. Cui X, Schiff R, Arpino G, et al. Biology of progesterone receptor loss in breast cancer and its implications for endocrine therapy. J Clin Oncol 2005;23:7721-35.

55. Horwitz KB, McGuire WL. Estrogen control of progesterone receptor in human breast cancer. Correlation with nuclear processing of estrogen receptor. J Biol Chem 1978; 253:2223-8.

56. Eifel P, Axelson JA, Costa J, et al. National Institutes of Health Consensus Development Conference Statement: adjuvant therapy for breast cancer, November 1-3, 2000. J Natl Cancer Inst 2001;93:979-89.

57. Bardou VJ, Arpino G, Elledge RM, et al. Progesterone receptor status significantly improves outcome prediction over estrogen receptor status alone for adjuvant endocrine therapy in two large breast cancer databases. J Clin Oncol 2003;21:1973-9.

58. Fitzgibbons PL, Page DL, Weaver D, et al. Prognostic factors in breast cancer. College of American Pathologists Consensus Statement 1999. Arch Pathol Lab Med 2000;124:966-78.

59. Markicevic M, Petrovic A, Kanjer K, et al. Estrogen-regulated cut-off values of $\mathrm{pS} 2$ and cathepsin D expression in breast carcinomas. Adv Exp Med Biol 2008;617:341-8.

60. Bardin A, Boulle N, Lazennec G, et al. Loss of ERbeta expression as a common step in estrogen-dependent tumor progression. Endocr-Relat Cancer 2004;11:537-51.

61. Jensen EV, Jordan VC. The estrogen receptor: A model for molecular medicine. Clin Cancer Res 2003;9:1980-9.

62. Mandusic V, Nikolic-Vukosavljevic D, Tanic $\mathrm{N}$, et al. Expression of estrogen receptor beta wt isoform (ERbetal) and ERbeta Delta5 splice variant mRNAs in sporadic breast cancer. J Cancer Res Clin Oncol 2007;133:571-9.

63. Esslimani-Sahla M, Simony-Lafontaine J, Kramar A, et al. Estrogen receptor beta (ER beta) level but not its ER beta cx variant helps to predict tamoxifen resistance in breast cancer. Clin Cancer Res 2004;10: 5769-76.

64. Honma N, Saji S, Kurabayashi R, et al. Oestrogen receptor-betal but not oestrogen receptor-betacx is of prognostic value in apocrine carcinoma of the breast. APMIS 2008;116:923-30.

65. Shaaban AM, Green AR, Karthik S, et al. Nuclear and cytoplasmic expression of ERbeta1, ERbeta2, and ERbeta5 identifies distinct prognostic outcome for breast cancer patients. Clin Cancer Res 2008;14: 5228-35.

66. Kuiper GG, Enmark E, Pelto-Huikko M, et al. Cloning of a novel receptor expressed in rat prostate and ovary. Proc Natl Acad Sci USA 1996;93:5925-30.

67. Leav I, Lau KM, Adams JY, et al. Comparative studies of the estrogen receptors beta and alpha and the androgen receptor in normal human prostate glands, dysplasia, and in primary and metastatic carcinoma. Am J Pathol 2001;159:79-92.

68. Horvath LG, Henshall SM, Lee CS, et al. Frequent loss of estrogen receptor-beta expression in prostate cancer. Cancer Res 2001;61:5331-5.

69. Imamov 0, Lopatkin NA, Gustafsson JA. Estrogen receptor beta in prostate cancer. N Engl J Med 2004;351:2773-4.

70. Imamov 0, Morani A, Shim GJ, et al. Estrogen receptor beta regulates epithelial cellular differentiation in the mouse ventral prostate. Proc Natl Acad Sci USA 2004; 101: 9375-80.

71. Fujimura T, Takahashi S, Urano T, et al. Differential expression of estrogen receptor beta (ERbeta) and its C-terminal truncated splice variant ERbetacx as prognostic predictors in human prostatic cancer. Biochem Biophys Res Commun 2001; 289:692-9.

72. Walton TJ, Li G, McCulloch TA, et al. Quantitative RT-PCR analysis of estrogen receptor gene expression in laser micro dissected prostate cancer tissue. Prostate 2009;69:810-9.

73. Jager W, Sauerbrei W, Beck E, et al. A randomized comparison of triptorelin and tamoxifen as treatment of progressive ovarian cancer. Anticancer Res 1995;15: 2639-42.

74. Chu S, Mamers P, Burger HG, Fuller PJ. Estrogen receptor isoform gene expression in ovarian stromal and epithelial tumors. $\mathrm{J}$ Clin Endocrinol Metab 2000;85:1200-5.

75. Warner M, Wang L, Weihua Z, et al. Analysis of estrogen receptor expression in tissues. Methods Enzymol 2003;364:448-63.

76. Weihua Z, Andersson S, Cheng G, et al. Update on estrogen signaling. FEBS Lett 2003;546:17-24.

77. Barria A, Leyton V, Ojeda SR, Lara HE. Ovarian steroidal response to gonado tropins and beta-adrenergic stimulation is enhanced in polycystic ovary syndrome: role of sympathetic innervation. Endocrinology 1993;133:2696-703.

78. Park W, Choi JJ, Hwang ES, Lee JH. Identification of a variant estrogen receptor lacking exon 4 and its coexpression with wild-type estrogen receptor in ovarian carcinomas. Clin Cancer Res 1996;2:202935 .

79. Suzuki F, Akahira J, Miura I, et al. Loss of estrogen receptor beta isoform expression and its correlation with aberrant DNA methylation of the 5'-untranslated region in human epithelial ovarian carcinoma. Cancer Sci 2008;99:2365-72.

80. Rodriguez C, Patel AV, Calle EE, et al. Estrogen replacement therapy and ovarian cancer mortality in a large prospective study of US women. JAMA 2001;285:1460-5.

81. Lacey JV Jr, Mink PJ, Lubin JH, et al. Menopausal hormone replacement therapy and risk of ovarian cancer. JAMA 2002; 288:334-41.

82. Anderson GL, Judd HL, Kaunitz AM, et al. Effects of estrogen plus progestin on gynecologic cancers and associated diagnostic procedures: the Women's Health Initiative randomized trial. JAMA 2003;290:1739-48.

83. Bardin A, Hoffmann P, Boulle N, et al. Involvement of estrogen receptor beta in ovarian carcinogenesis. Cancer Res 2004; 64:5861-9.

84. Chan KKL, Wei N, Liu SS, et al. Estrogen Receptor Subtypes in Ovarian Cancer: A Clinical Correlation. Obstet Gynecol 2008; 111:144-51.

85. Deligdisch L, Holinka CF. Endometrial carcinoma: two diseases? Cancer Detect Prev 1987;10:237-46.

86. Grady D, Gebretsadik T, Kerlikowske K, et al. Hormone replacement therapy and endometrial cancer risk: a meta-analysis. Obstet Gynecol 1995;85:304-13.

87. Fisher B, Costantino JP, Wickerham DL, et al. Tamoxifen for prevention of breast cancer: report of the National Surgical Adjuvant Breast and Bowel Project P-1 Study. J Natl Cancer Inst 1998;90:1371-88.

88. Schultz JR, Petz LN, Nardulli AM. Cell- and ligand-specific regulation of promoters containing activator protein-1 and Sp1 sites by estrogen receptors alpha and beta. J Biol Chem 2005;280:347-54.

89. Paech K, Webb P, Kuiper GG, et al. Differential ligand activation of estrogen receptors ERalpha and ERbeta at AP1 sites. Science 1997;277:1508-10.

90. Pinkerton JV, Goldstein SR. Endometrial safety: a key hurdle for selective estrogen receptor modulators in development. Menopause 2010;17:642-53. 